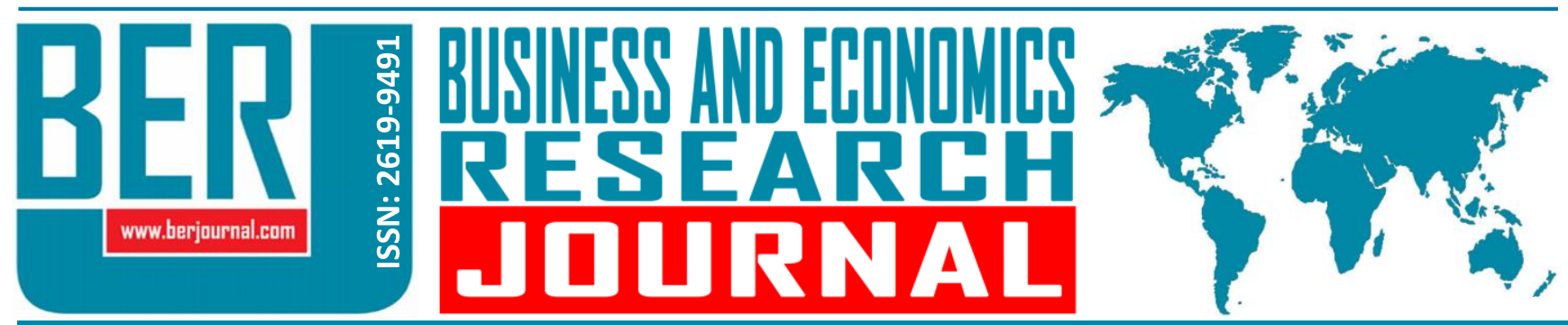

Business and Economics Research Journal Vol. 11, No. 3, 2020, pp. 823-839 doi: 10.20409/berj.2020.284

\section{Suçlu Kim? İtkisel (Anlık) Satın Alma Davranışı ve Gıda İsrafı Arasındaki İlişkinin Atfetme Teorisi Perspektifinden Değerlendirilmesi}

\begin{abstract}
Gulnil Aydin ${ }^{\mathrm{a}}$, Sabahattin Celik ${ }^{\mathrm{b}}$
Öz: Bu çalışmanın amacı; itkisel satın alma davranışı ve gıda israfı arasındaki ilişkiyi ve itkisel (anlık) satın alma davranışı sergileyen tüketicilerin, israf durumunda, sorumluluğu/suçu kimlere (kendilerine, aile içindeki diğer bireylere, pazarlama profesyonellerine) atfettiğini araştırmaktır. Bu amaçla gerçekleştirilen çalışmada, veri toplamak için anket tekniğinden yararlanılmıştır. 324 katılımcıdan veri toplanmıştır. Verilere uygulanan faktör analizi, kümeleme analizi ve t-testleri sonucunda elde edilen bulgular -itkisel satın alma eğilimi ile gıda israfı arasında bir ilişki bulunmasına rağmenbu ilişkinin israfı artırıcı boyutta olmadığına işaret etmiştir. Ayrıca itkisel satın alma eğilimi sergileyenlerin, planlı alışveriş eğilimi gösterenlere kıyasla, yaşanılan israf konusunda pazarlama uygulamacılarını daha fazla suçladıkları görülmüştür. Çalışmanın sonuç kısmında elde edilen bulgular ışığında uygulamacılara öneriler sunulmuştur.
\end{abstract}

\section{Who is guilty? Evaluation of the Relationship Between Impulsive Buying Behavior and Food Waste from Perspective of Attribution Theory}

\begin{abstract}
The aim of this study is to investigate the relationship between impulsive buying behavior and food waste, and to whom (to themselves, to other individuals in the family, to marketing professionals) consumers showing impulsive buying behavior attribute responsibility/crime as a result of waste. For this purpose, the survey method was used to collect data in the study. Data was collected from 324 participants. Findings obtained as a result of factor analysis, cluster analysis and t-tests applied to the dataalthough there was a relationship between impulsive buying tendency and waste of food-pointed out that this relationship is not waste-increasing. In addition, compared to those who show impulsive buying tendency and those with a tendency to planned buying; it was observed that they accused marketing practitioners more about wastage. In the light of the findings obtained in the conclusion of the study, suggestions were presented to the marketing practitioners.
\end{abstract}

Anahtar Sözcükler: Gıda İsrafı, İtkisel (Anlık) Satın Alma, Atfetme Teorisi, Kontrol Odağı, Duygu

JEL: M31, Q01, Q13

$\begin{array}{ll}\text { Geliş } & : 23 \text { Mart } 2020 \\ \text { Düzeltme } & : \text { 12 Mayıs } 2020 \\ \text { Kabul } & : \text { 04 Haziran } 2020 \\ \text { Tür } & : \text { Araştırma }\end{array}$

Keywords: Waste of Food, Impulsive Buying, Attribution Theory, Locus of Control, Emotion

JEL: M31, Q01, Q13

$\begin{array}{ll}\text { Received } & : 23 \text { March } 2020 \\ \text { Revised } & : 12 \text { May } 2020 \\ \text { Accepted } & : \text { 04 June } 2020 \\ \text { Type } & \text { : Research }\end{array}$

a Asst. Prof., PhD., Bandirma Onyedi Eylul University, Faculty of Economics and Administrative Sciences, Department of Business Administration, Balikesir, Turkiye, gaydin@bandirma.edu.tr (ORCID ID: 0000-0002-5613-920X)

b Lecturer, PhD., Istanbul University, Cerrahpasa Vocational School of Social Sciences, Istanbul, Turkiye, sabahattin.celik@gmail.com (ORCID ID: 0000-0002-1733-6235) 


\section{Giriş}

Tüketim, insanoğlunun varoluşundan bugüne dek özellikle yeme, içme, barınma ve güvenlik gibi temel fizyolojik intiyaçlarını karşılama niyetiyle gerçekleştirilen bir olgudur. İnsanlar çeşitli mal ve hizmetleri tüketerek söz konusu ihtiyaçlarını karşılamaktadırlar. Günümüz dünyasında; zorunlu tüketim, hedonik tüketim, sembolik tüketim, gösteriş tüketimi gibi farklı tüketim tarzlarından bahsedilmektedir (Aksoy ve Solunoğlu, 2015; Koç, 2019). Ancak giderek artan nüfus ve farklı tüketim alışkanlıkları yeryüzünde gıdanın yanı sıra temiz hava, su ve toprak gibi yenilenmesi zor veya imkansız kaynakların gereksiz yere kullanılarak israf edilmesine yol açmaktadır.

Gıda israfı ve kaybı son yıllarda hem bilimsel hem de küresel açıdan üzerinde fazlaca konuşulan bir konu haline gelmiştir. Tarım sektöründe çevresel ayak izinin azaltılması ve fakir ülkelerin açlık, yoksulluk/sefaletinin giderilmesi için gıda kayıp ve israfında azaltıma gidilmesi küresel bir konu olarak değerlendirilmektedir. 2011 yııında Birleşmiş Milletler Dünya Gıda ve Tarım Organizasyonu (Food and Agriculture Organization-FAO)'nun, gıda israf ve kaybının dünya genelinde üretilen toplam miktarın 1/3'ü olduğuna ilişkin tahminini paylaşmasıyla konu daha bir ciddiyet ve önem kazanmıştır. Dolayısıyla her yıl 1,3 milyar ton gıda, insanların tüketimine sunulmak üzere üretilmekte ve bu üretimin üçte biri yok olmakta veya israf edilmektedir (FAO, 2011; Demirbaş, 2019). Tüketilemeyecek/israf edilen gıdaları üretmek için küresel olarak kullanılan su miktarının, 9 milyar insanın su tüketim ihtiyacını karşılayacak düzeyde olması da ayrıca üzerinde durulması gereken bir konudur (FAO, 2013; Aksoy ve Solunoğlu, 2015). Avustralya ve ABD'de ise her yıl 3 - 4 milyon ton yenilebilir gıda çöp olmaktadır. Benzer şekilde, her yıl yakalandıktan sonra 6,8 milyon ton balık (küresel avın \%8'i) atılmaktadır (Newsome ve Eeden, 2017).

Buna karşılık -iyileşmelere rağmen- hala dünyanın birçok ülkesinde açlık önemli boyuttadır. Aç nüfus sayısı neredeyse $A B D$, Kanada ve $A B$ 'nin toplam nüfusuna eşittir. Dünyada aç nüfusu besleyecek gıda yeterli düzeyde üretilmekle beraber, kayıp ve israf edilen gıda miktarı Sahra altı Afrika'nın yaklaşık 5-6 yıllık toplam gıda üretimine eşdeğerdir (Dölekoğlu, 2017).

FAO'nun tahminlerine göre, 2050 yılına kadar dünya nüfusu 9,1 milyarı bulacak, bir başka ifadeyle 10 milyara yaklaşacaktır (FAO, 2009). Artan nüfusa bağlı olarak, gıda talebinin de iki kat artması beklenmektedir. Buna bağlı olarak, tarladan sofraya gıda arz zinciri boyunca ürünlerin kayıp ve israfının önlenmesi, giderek daha önemli hale gelmektedir. 7-8 Mayıs 2015'de İstanbul'da düzenlenen G20 Tarım Bakanları Toplantısında belirlenen "Sürdürülebilir Gıda Sistemlerinin Tesis Kapsamında Gıda İsrafı ve Kayıpları" ana teması kapsamında; sonuç bildirgesinde, gıda sistemlerinin etkinliğinin iyileştirilmesi, israfın azaltılmasında alınacak önlemler için ekonomik ve fiziksel olarak gıda israfının belirlenmesi ve etkilerinin ortaya konulması için ortak anlayışın benimsenmesi kararı yer almıştır. G20'nin bu konuda küresel liderlik yapabileceğine dikkat çekilmiştir (Tarım ve Orman Bakanlığı, 2015).

Tüm ülkeler; değişen tüketici alışkanlıkları, hızlı kentleşme, süpermarket zincirlerinin yaygınlaşması ve beslenme tercihleri gibi yaşam tarzlarındaki değişmelerden etkilenmektedir. Gıda kayıp ve israfı konusunda Türkiye'deki mevcut durum da küresel gelişmelerden farklı değildir (Demirbaş, 2019).

Gıda kaybı ve israfını iki farklı kavram gibi değerlendirenler olmasına karşın; farklı olduğunu vurgulayanlar da bulunmaktadır. Kayıp ve israfı tanımlamak için, gıda tedarik zincirinden yararlanılmaktadır. Gıda tedarik zinciri genel olarak; üretim, hasat, işleme, depolama, dağıtım ve tüketim aşamalarından oluşmaktadır (Gustavsson vd., 2011; Salihoğlu vd., 2018). FAO (2014) ile Parfitt vd. (2010)'ne göre; gıda israfı tüketim ve ona yakın perakendecilik yani dağıtım aşamasında ortaya çıkan kayıpları tanımlamak için kullanılmaktadır. Dünya Araştırma Enstitüsü (WRI- World Resource Institute) ise gıda israfını, sadece tüketiciler nezdinde yaşanan atıklarla ifade etmektedir. Hodges vd. (2010), hasat sonrası gıda kaybının bir parçası olarak, perakende ya da tüketici seviyelerinde tüketilebilecek, ancak herhangi bir nedenle tüketilmeyen gıdayı 'israf' olarak tanımlamıştır (akt. Dölekoğlu, 2017).

Gıda zincirinde ortaya çıkan bu israf/kayıpların farklı nedenlerinden bahsedilmektedir: Hanelerde; israfın farkında olmamak, liste oluşturmadan alışveriş yapmak, ürün kullanım tarihi ve etiket içerikleri hakkında yeterli düzeyde bilgi sahibi olmamak, cazip tekliflerle satın alma sayısının artırılması gibi nedenler, 
israfı tetikleyici unsurlar olarak değerlendirilmektedir (Aksoy ve Solunoğlu, 2015). Dolayısıyla ilk etapta bu nedenlerin ortadan kaldıılması önem taşımaktadır. Bunun için geliştirilen öneriler; tüketicilerin bilinçli satın alma davranışları sergilemeleri, alışveriş listesi yapmaları, tüketebilecekleri miktarı sağlıklı biçimde öngörmeleri vb. yönündedir. Bireylerin daha bilinçli davranabilmeleri için öncelikle sorumluluk hissetmeleri önem taşımaktadır. Bu noktada akla gelen soru bireylerin ne düzeyde sorumluluk hissettikleri ile ilgilidir.

Tüketicilerin israfa yönelmelerinde etkili olabilecek faktörler üzerine detaylı araştırmalar yapılması önem taşımaktadır: Bir örnek vermek gerekirse; Williamson vd. (2016), yemeklerini atılabilir tabaklarda yiyen bireylerin, normal tabaklardan tüketenlere kıyasla daha fazla gıda israfına yöneldiklerini tespit etmişlerdir. Bu bulgu, gıda israfı konusunda önlem alınabilecek bir konuya işaret etmektedir.

Gıda israfının tüketici yönlü nedenlerini belirleme üzerine gerçekleştirilen bir araştırmada (Aschemann-Witzel vd., 2015), israfın sebeplerinden birinin pazarlama faaliyetleri kapsamında yürütülen fiyatlandırma ve ambalajlama çalışmaları olduğu ifade edilmektedir. Perakendeciler gıdalara yönelik kullandıkları ambalajlama ve fiyatlandırma stratejileri (fiyat indirimleri, yüksek miktarlarda veya büyük ambalajda satın alındığında fiyatların daha cazip sunulması vb.) ile tüketicileri etkilemektedirler. Hem perakendeciler hem de üreticiler ambalajlar üzerinde depolama bilgileri, dondurma vs. işlemlerine ilişkin yönlendirmeler, etiketler vs. konularında hangi bilgilere yer verilip verilmeyeceğini belirleyerek tüketici kararları üzerinde etkili olabilmektedirler.

Tüketiciler, satın alma sürecinde, çok farklı faktörlerin etkisiyle kararlarını şekillendirmektedirler. Tüketicilerin ürün ve hizmet satın alımlarının \%95'i itkisel satın alma davranışıyla açıklanmaktadır (Koç ve Boz, 2014). Bu yüksek oran, tüketicileri anlama noktasında, itkisel satın alma davranışının önemini vurgulamaktadır. Tüketicileri itkisel davranışa iten çok farklı faktörlerden bahsedilmektedir. Bunlar arasında 'ürün niteliği' de sayılmaktadır. Gıda satın alımları da, itkisel satın alma davranışıyla gerçekleştirilebilmektedir. Tüketicilerin, planlama yapmaksızın alışverişlerini yapmaları, satın alma sonrası davranışlarını da etkilemektedir. Yukarıda bahsedildiği üzere plansızlık israfta önemli görülmektedir. Dolayısıyla itkisellikte etken faktörleri açıklamak, tüketicileri anlayabilmek açısından önemlidir.

Her ne kadar tüketicilerin satın alma davranışlarında, planlı veya anlık eğilimlerin, gıda israfında önemli rol oynadığı ifade edilse de, bireylerin gıda israfının nedenlerini nasıl açıklayacağı da önemlidir. Tüketicilerin gıda israfında sorumluluğu/suçu kime atfedecekleri, israfla ilgili alınacak önlemler açısından belirleyici olabilecektir. Ayrıca israfla sonuçlanabilecek satın alma kararlarının sonucunda tüketicilerin nasıl bir duygudurum içinde oldukları da, aynı davranışı tekrar edip etmeyecekleri hususunda açıklayıcı olabilecektir.

Bu kapsamda çalışmanın amacı; itkisel satın alma davranışı ve gıda israfı arasındaki ilişkiyi ve itkisel (anlık) satın alma davranışı gösteren bireylerin, israfla karşılaşmaları sonucunda, bunun sorumluluğunu ve suçunu kimlere (kendilerine, aile içindeki diğer bireylere, pazarlama profesyonellerine) atfettiğini araştırmaktır. Bireylerin, israf sorumluluğu ve suçunu kendilerine atfetmeleri durumunda, davranış değişikliği ve önlem alma eğilimleri daha yüksek olabilecektir. Bu amaçla gerçekleştirilen çalışmada öncelikle kavramsal çerçeve oluşturulmuş, sonrasında ampirik çalışmaya yer verilmiştir.

\section{Kavramsal Çerçeve}

\subsection{Gıda İsrafı ve Kaybı}

İsraf, kıt kaynakların etkin kullanımı bakımından, sonuçları ciddi boyutlara ulaşan ve uzak durulması gereken bir davranış olarak tanımlanmaktadır. Oldukça önemli büyüklüklere ulaşan israfın, azaltılması yönünde önlemler alınmaya çalışımakta, bu konuda bireylerin duyarlı ve bilinçli davranış sergilemeleri büyük önem taşımaktadır. Bu duyarılıık ve bilinçle, tüketicilerin israfı azaltmaları ve davranışlarını israfı azaltıcı yönde değiştirmeleri gerekmektedir. Davranış değişiklikleri, akademik çalışmalarda, genellikle planlı eylem modeli çerçevesinde tartışılmaktadır. Bu yaklaşım bireylerin tutarlı ve planlı eylemler içinde davrandığını varsaymaktadır. Bu modele göre; bir bireyin davranış değişikliğine gitmesi veya yeni bir ürünü kabul etmesinde, ona karşı geliştirdiği tutumun ve algıladığı faydanın önemi büyüktür. 
Ancak bunun yanında, tüketicilerin çoğu tüketim kararlarında zaman zaman tutarsız veya bilinçsiz davranışlar sergileyebildiği gözlemlenmektedir. Block vd. (2016)'nin iddiasına göre; tüketicilerin yarattığı gıda israfının çoğu, bilinçli bir şekilde farkında olunmayan veya tutumlarla açıklanmayan bir nedenle ortaya çıkabilmektedir. Yazarlara göre, gıda israfında bireyler kasti bir eylem içinde olmadığından, konuya psikolojik boyutlarla yaklaşmak gerekmektedir.

Bireylerin kasten israf etmedikleri düşünüldüğünde satın alma kararında hangi hatalar veya yanılgılar gıda israfıyla sonuçlanabilecektir? Tüketici davranışında tanımlayıcı yaklaşımlara göre, bireyler satın alma kararlarını bir süreç sonucunda vermektedirler (Altunışık vd., 2017). Bu sürecin farklı aşamalarında bireyler seçimleriyle israfa zemin oluşturabilmektedirler. Mesela; tüketiciler satın aldıkları gıdaları tüketebilecekleri konusunda iyimser davranmaktadırlar veya zamansızlık hızlıca ürün satın almalarını mümkün kılabilmektedir. Ayrıca satın alma kararlarında çok yönlendirildiklerini düşündüklerinde, israftan başkalarını sorumlu tutabilmektedirler (Block vd., 2016). Sözgelimi, restoranda kendilerine yemek tavsiyesinde bulunan ve servisi üstlenen garson israfla sonuçlanan siparişlerden sorumlu tutulabilecektir. Bell vd. (1994)'ne göre bir faaliyetle ilgili karar ve düzenleme yetkisi devredildiği zaman, o karar sonucunda ortaya çıkabilecek negatif/pozitif sonuçların devri de gerçekleşebilecektir. Bu nedenle örneğin, bir restoranda yemek siparişi veren kişi porsiyon büyüklüğünün garson ve aş̧̧ı tarafından belirlendiği durumda, tüketemediği israf edilen yiyeceklerin sorumluluğunu, onlara yani garsonlara veya aşçıya atfedebilecektir. Ancak ilginçtir ki; özellikle turizm alanında self servis uygulamalarda ve açık büfe sunumlarda, her ne kadar porsiyon büyüklüğünü müşteriler kendileri belirleseler bile israf gerçekleşebilmektedir. Bu durumda da tüketiciler cezbedici sunumlar ve satış odaklı uygulamalar nedeniyle etkilendiklerini belirterek, ortaya çıkan negatif sonuçlardan yine başkalarını sorumlu tutabilecektir.

Yukarıdaki açıklamalar doğrultusunda, tüketicilerin satın alma davranışları kapsamında, israfla ilişkilendirilebilecek, itkisel (anlık) satın alma davranışı ve atfetme eğilimlerine iliş̧in teorik değerlendirmelerin yapılması gerekmektedir.

\section{2. İtkisel (Anlık) Satın Alma Davranışı}

Sharma vd. (2014), tüketicilerin satın alma davranışını rutin satın alma, sınırlı problem çözme, yoğun/kompleks satın alma davranışı ve itkisel satın alma davranışı olarak kategorize etmiştir (Oladipo, 2019). İtkisel satın alma davranışının nasıl tanımlandığı araştıııldığında farklı yaklaşımların mevcut olduğu görülmektedir (Piron, 1991).

İlk yaklaşımda, itkisel satın alma; anlık bir karar ile ürünün satın alımının söz konusu olduğu plansız davranışlar olarak tanımlanmaktadır. Piron (1991) itkisel satın alma davranışıyla ilgili ilk araştırmalara bakıldığında, ağırlıkı olarak plansız satın alma eğilimine ilişkin değerlendirmelerin baskın olduğunu ifade etmektedir. Rook ve Gardner (1993) itkisel satın almayı, hızlı karar alma ve ürünün hemen elde edilmesini içeren planlanmamış bir davranış olarak tanımlamıştır.

ikinci yaklaşımda; itkiselliğin bir uyarıcıya maruz kalma durumuyla ortaya çıktığı ifade edilmektedir. Kacen ve Lee (2002)'ye göre itkisel satın alma davranışı planlı davranışla kıyasla bilinçliliğin daha düşük (less deliberative) kışkırtııılığın daha fazla (more arousing) olduğu durumlarla açıklanmaktadır. Dolayısıyla tüketici davranışlarını planlı, plansız veya tepkisel olarak sınıflandırmak mümkündür (Hausman, 2000'dan akt. Yeniçeri vd., 2012). Üçüncü yaklaşımda; itkisel satın alma davranışının hızlı, anında gerçekleşen bir davranış olma özelliğine vurgu yapılmaktadır. Sonuncu yaklaşımda ise; tüketicinin gelecek sonuçlar için gözardı ettiği ve suçluluk hissi içerebilen duygusal ve bilişsel tepkileri deneyimleyebileceği satın alma davranışıdır (Taşkın ve Özdemir, 2017) Nitekim, Verplanken ve Herabadi (2001), tüketicinin itkisel satın alımının bilişsel ve duygusal olarak iki boyutla açıklanabileceğini belirtmiştir. Bilişsel boyut; ağırlıklı olarak plansızlıkla ilgili olarak tanımlanırken, duygusal boyutta ise haz ön plana çıkmaktadır (Murugarantham ve Bhaket, 2013).

Tanımlardaki ve yaklaşımlardaki farklıııklar, itkisel satın alma davranışının, farklı biçim ve özelliklerle ortaya çıkabileceğini düşündürmektedir. Madhavaram ve Laverie (2004), bu farklııkları gruplandırdığı çalışmasında, "saf itkisel satın almayı; planlamanın kesinlikle olmadığı, genel olarak tanımlanan satın alma davranış kalıplarına uymayan yeni bir davranış türü" olarak açıklarken, "hatırlatıcı itkisel satın almayı; kişinin 
daha önceki deneyimlediği satın alımlara dayanan davranış tipi", "teklifli itkisel satın almayı; tüketici bir ürünü ilk kez gördüğünde gerçekleştirdiği değerlendirmelere dayalı olarak ortaya çıkan davranış biçimi" olarak ve planlı itkisel satın almayı da; farklı indirimleri takip eden bireyler tarafından sergilenen davranış biçimi" olarak açıklamışlardır.

Koç ve Boz'a (2014) göre itkisel satın alma eğilimi; tüketiciyi, bir ürünü satın alma sırasında değerlendirmeden geçirerek seçme, ya da otokontrol sağlayarak satın almayı ertelemekten ziyade, o ürüne hemen sahip olma yönünde motive etmektedir. Tüketicilerin anında sonuca gitmelerine ve hızlıca karar vermelerine yol açması nedeniyle, itkisellik sonucunda yanlış kararlar verilebilecektir. Ancak bununla birlikte tüketiciler tarafından yapılan ürün ve hizmet satın alımlarının \%95'inin bu şekilde gerçekleştiği belirtilmektedir (Koç ve Boz, 2014). Yine başka bir çalışmaya göre; İngiltere'de tüketicilerin yıllık olarak itkisel satın alımlarının tutarı 21,7 milyar Euro'yu bulabilmektedir (Parsad vd., 2019).

İtkisel satın alma davranışı farklı yaklaşım ve bakış açılarıyla tanımlanmış olmasına karşın, genel olarak bakıldığında itkisellik, satın alma karar sürecinde yer alan bilgi araştırma kısmını yapmadan planlamanın olmadığı, karar sürecine hızlı bir şekilde girilen haz odaklı, yönlendirici ve ani olma özellikleri ile ön plana çıkan karmaşık bir davranıştır (Bhuvaneswari ve Krishnan, 2015; Boz ve Koç, 2018). Plansızlığın öne çıkması, itkisel satın alma davranışının gıda israfıyla ilişkilendirilmesini mümkün kılmaktadır. Bireysel tüketim düzeyinde çoğu uzman, özellikle yiyecek ve yemek satın alma, depolama, hazırlama ve yeniden kullanmada israfın temel nedeninin, planlama ve yönetim eksikliği olduğunu vurgulamaktadır. Tüketimcilik (consumerism) kültürü ve bolluk, uygun gıda fiyatlarıyla birleşince, tüketiciler israf riskini çok fazla düşünmeden tüketmeye yönelmektedir (Aschemann-Witzel vd., 2015).

Anlık satın alma, mağaza içinde satın alma kararı verme anlamına gelmektedir. Dolayısıyla bu tür satın almayı, mağaza içinde sunulan öneriler etkileyebilmektedir. Mağaza içindeki uyarıcı, tüketici için unuttuğu bir intiyacı hatırlatmakta veya hissettirmektedir. Altunışık ve Mert (2003), itkisel satın alma davranışında mağaza içi satış geliştirme çalışmalarının etkili bir faktör olarak değerlendirilmesi gerektiğini ifade etmektedirler (akt. Aytekin ve Ay, 2015). Bell vd. (1994)'ne göre; plansız satın alma, arzu edilir fiyat seviyesi nedeniyle tek bir perakendecinin müşterisi durumunda olan alıcılarda, çok perakendeciyle çalışan müşterilerden daha yüksektir.

Tüketiciler; farklı faktörlerin etkisi altında kalmaları nedeniyle, satın alma davranışları neticesinde ortaya çıkan her tür negatif ve pozitif sonuçları, kendilerine veya dışsal aktörlere atfedebilecektir. Bu açıdan çalışmanın sonraki kısmında atfetme teorisinden bahsedilmektedir.

\subsection{Atfetme Teorisi (Yükleme Kuramı)}

Insanlar, çevresinde olup bitenleri kestirebilme, onları kontrol etme ve anlamlandırma ihtiyacı duymaktadırlar. Bu anlamlandırma sürecinde kişiler, olaylar ve davranışlar arasında nedensellik bağlantıları kurmaktadırlar. Atfetme, insanların bir davranışa ya da olaya neden ataması ve sonuç çıkarması süreci olarak tanımlanabilir (Kelley, 1973'den akt. Bahar, 2019). Bireylerin davranışlarının ya da olayların nedenini belirleme sürecini ifade eden atfetme hakkında ilk kuramsal çalışmaları yapan kişi Fritz Heider (1958) olmuştur.

Heider'in Naif Bilim Adamı yaklaşımına göre; insanların davranışlarına buldukları nedenleri içsel (kişisel) ve dışsal (kişisel olmayan) olarak iki gruba ayırmak mümkündür. İçsel atıf; kişinin kendisi ile ilgili niteliklerdir. İçsel atıfta, kişilik özellikleri, bireyin yetenekleri, gayreti ve ruh hali dikkate alınır. Dışsal atıf ise; kişinin kendisi dışındaki faktörleri örneğin; başka bireylerin davranışı, şans, o kişinin içinde bulunduğu koşullar gibi unsurların ön plana çıktı̆̆ı durumları içermektedir. Heider, bireylerin içsel ve dışsal atıflarının bileşimiyle davranışlarına yön verdiğini kabul etse de, bireylerin aslında belirli bir eylemi genel olarak içsel durumlara dayanarak açıklama eğiliminde olduklarını belirtmektedir (Ay ve Kahraman, 2014)

Weiner (1986), Heider'in atıflarla ilgili kurduğu kuramı genişletmiştir. Dört temel nedensel atfın (içsel: yetenek, çaba; dışsal: işin zorluğu ve şans) yanısıra, davranışın kalıcılık/durağanlık derecesini ve kontrol edilebilirliğini de analize dahil edilmiştir. Kalıcılık/durağanlık, içsel ya da dışsal nedenlerin kalıcı olup 
olmamasıyla ilgiliyken, kontrol edilebilirlik, kişinin olumlu/olumsuz veya başarılı/başarısız olarak değerlendirdiği durumların, kendisi tarafından ne kadar kontrol edilebilir olarak algılandığını ifade etmektedir (Maymon vd., 2018). Bu nedenle kontrol algısı; karşılaşılan olumlu olumsuz durumlarda sorumluluğun ne kadarının birey tarafından üstlenilebileceği, ne kadarının başkalarına/çevreye atfedileceği üzerinde belirleyici olabilmektedir.

Bireyler yaşadıkları olayların nedenlerine ilişkin sorgulama yaparken, bazı yanılsamalara düşebilirler. Örneğin, herhangi bir olaya herkesin kendisiyle aynı tepkiyi verdiğini düşünme eğiliminde olmaları veya kendini kayırma eğilimi taşımaları gibi... Kendini kayırma eğilimi, kişinin başarıyı kendisine mal ederken, başarısızlık için ise suçu dış etmenlere yüklemesidir. Bu durumda, başarılar daha ziyade yetenek, çok çalışmak gibi içsel nedenlere yüklenirken, başarısızlıkların nedenleri ise kötü şans, baskıcı bir yönetim anlayışı, havanın yağışlı olması gibi dışsal etkenler olarak görülebilmektedir (Ay ve Kahraman, 2014). Bu durumdan hareketle israf durumuyla karşılaşan bir bireyin, toplumsal olarak da onaylanmayan bu negatif sonuca ilişkin nedenselliği, dışsal faktörlere yüklemesi mümkün olabilecektir.

Atfetme teorisine göre nedensel durumlara ilişkin açıklamalar, bireylerin duygu ve davranışlarını etkilemektedir. Bu modelde duygular, kontrol odağı (locus of control) ile ilgili olarak gurur, değişkenlikle/durağanlıkla ilgili olarak ümit ve kontrol edilemezlikle ilgili olarak ise kızgınlık, suçluluk ve utanç olarak ortaya çıkmaktadır. Daha spesifik olarak, gerçekleşen başarısızlık durumunda, kişisel kontrolün belirtildiği atıflarda suçluluk duygusunu daha baskın hissederken, içsel fakat kişisel olarak kontrol edilemeyen atıflarda ise, utanç duygularıyla sonuçlanan bir süreçten bahsedilebilmektedir (Maymon vd., 2018)

Gıda israfı konusunda da bazı araştırmacılar (Stefan vd., 2013; Quested vd., 2013) çoğu tüketicinin savurgan davranışlarda bulunurken, kendilerini rahatsız ya da suçlu hissettiklerini tespit etmişlerdir. Bu bağlamda, suçluluk ahlaki bir normun pozitif bir göstergesi olarak kabul edilir ve davranış değişikliği niyeti konusunda da bir işaret olarak değerlendirilebilir. Bir başka ifadeyle, suçluluk duyan bir bireyin benzer bir davranışı tekrar etmeme niyeti daha yüksek olabilecektir (Graham-Rowe vd., 2015; Porpino vd., 2016).

\section{Araştırma Metodolojisi}

Anakütle İstanbul ilinde yaşayan 18 yaş üzeri bireylerdir. Çalışmada veri toplama aracı olarak anket tekniğinden yararlanılmıştır. Çalışmanın verileri Statistical Consulting Araştırma Şirketi tarafından tüketici paneli kullanılarak toplanmıştır. Anket formunda yer alan ölçek ifadelerine ilişkin detaylı bilgi Tablo 1'de görülmektedir. Gıda israfı konusunda katılımcıların sosyal beğenirlik etkisiyle cevaplarında yönlendirici olmamak adına anket çevrimiçi platformda gerçekleştirilmiştir (Temmuz 2019 ile Aralık 2019 tarihleri arasında anket çevrimiçi yayında kalmıştır). Anketi toplam 370 katılımcı cevaplamıştır. Örneklem sayısı belirlenirken; evren büyüklüğü 10 milyon üzeri, gıda israfı gözlenme ve gözlenmeme olasılığı (p/q değerleri) \%60/\%40, \%95 güven aralığı ve 0,05 anlamlılık düzeyi için kabul edilebilir örnekleme hatası 0,05 olarak alınmıştır (Altunışık vd., 2012). 2019 yılı nüfus istatistiklerine göre; araştırmanın yürütüldüğü il olan İstanbul'un nüfusu 15.519.267'dir (TUiK, 2020). Bu sayının yaklaşık \%70'inin 18 yaş ve üzeri olduğu düşünüldüğünde evren büyüklüğü 10 milyonun üzerindedir (10.015.960). Bu değerlendirmeler ışığında belirlenen örneklem sayısı 368' dir. Katılımcılar tarafından toplam 370 anket doldurulmuş, ancak analizler için sağlıklı verilerin yer aldığı 324 anket değerlendirmeye alınmıştır.

Çalışma aşağıdaki sorulara cevap aramak amacıyla gerçekleştirilmiştir:

1. İtkisel satın alma eğilimi ile gıda israfı arasında bir ilişki var mıdır?

2. Gıda israfında sorumluluğu/suçu dışarıya (pazarlama uygulamacılarına ve diğer aile bireylerine) atfetme eğilimi, itkisel satın alma davranışı sergileyenler ile planlı davrananlar arasında farklılık göstermekte midir?

3. İtkisel satın alma eğilimi taşıyanların, planlı alışveriş eğilimi gösterenlere kıyasla, daha düşük kontrol algısına sahip oldukları söylenebilir mi? 
4. İtkisel (anlık) satın alma eğilimi sergileyenler ile planlı davrananlar, israfla karşılaştıkları zaman hangi duyguları yaşamaktadırlar? Iki grup duygu durumları itibariyle birbirinden ayrılmakta mıdır?

Tablo 1. Çalışmada Kullanılan Ölçekler ve İlgili Kaynaklar

\begin{tabular}{|c|c|}
\hline Değişkenler ve Ölçek ifadeleri & Referanslar \\
\hline IMBuY: İtkisel Satın Alma / Bilişsel İtkisellik & \multirow{11}{*}{ Verplanken vd. (2001) } \\
\hline Bir şey satın almadan önce dikkatlice düşünürüm * & \\
\hline Genelde sadece almayı amaçladığım şeyleri satın alırım * & \\
\hline Eğer bir şey satın alacaksam, genelde aniden (spontan) satın alırım ** & \\
\hline Alışverişlerimin çoğunu önceden planlarım * & \\
\hline Sadece, gerçekten ihtiyacım olan şeyleri satın alııım * & \\
\hline Bir şeyleri görür görmez satın almak benim tarzım değildir * & \\
\hline Bir şey satın almadan önce farklı markaları karşılaştırırım * & \\
\hline Bir şey satın almadan önce ihtiyacım olup olmadığını etraflıca düşünürüm * & \\
\hline Bir şeyleri gördüğüm anda satın almaya alışığımdır & \\
\hline Genelde düşünmeden bir şeyler satın alırım & \\
\hline IMBuY: İtkisel Satın Alma (Weun İçgüdüsel Satın Alma Ölçeği) & \multirow{6}{*}{$\begin{array}{l}\text { Weun vd. (1997) } \\
\text { Torlak ve Tiltay (2010) } \\
\text { Dursun ve Yener (2014) }\end{array}$} \\
\hline Alışverişe çıktığımda almaya niyetli olmadığım bazı şeyleri satın alırım & \\
\hline Plansız satın almalar yapan biriyim & \\
\hline Gerçekten ilginç bir şey gördüğümde sonuçlarını düşünmeksizin onu satın alırım & \\
\hline Sebepsiz olarak satın almak eğlencelidir & \\
\hline Alışveriş listemde olmayan şeyleri satın almaktan kaçınırım & \\
\hline Kontrol Odağı & \multirow{8}{*}{$\begin{array}{l}\text { Perry ve Morris (2005) } \\
\text { Aydemir (2015) }\end{array}$} \\
\hline Problemlerimin bir kısmını çözebilme imkânım gerçekten yok & \\
\hline Hayatın içinde itilip kakılıyorum. & \\
\hline Hayatımdaki önemli şeyleri değiştirmek için yapabileceğim çok az şey var & \\
\hline Kafama koyduğumu her zaman yapamayabilirim & \\
\hline Gelecekte başıma ne geleceği sadece bana bağılı değil & \\
\hline Hayatın problemleriyle baş etmede çaresizim & \\
\hline Başıma gelen şeylerde çok az kontrole sahibim & \\
\hline
\end{tabular}

Çalışmada katılımcıların hem planlı alışveriş eğilimleri hem de itkisel satın alma davranışlarını değerlendirmek gerektiğinden Weun vd. (1997)'nin itkisel satın alma eğilimi ölçeğinin yanısıra, Verplanken vd. (2001)'nin itkisellik ölçeğinin bilişsel satın alma boyutu da kullanılmıştır.

\section{Analiz ve Bulgular}

324 katılımcının cevapladığı anket formunda yer alan demografik sorulara ilişkin dağılımlar Tablo 2'de paylaşıımıştır. Farklı gelir gruplarını temsil eden katıımcıların yaş ağırlığının 18-30 aralığında yer aldığı görülmektedir (\%40). Cinsiyet itibariyle kadın ve erkek katılımcılarının yüzde oranlarının birbirine yakın olduğu dikkate çekmektedir.

Katılımcıların gıda israfı ile ilgili davranışsal özellikleri Tablo 3'de yer almaktadır. Tablodan anlaşılacağı üzere; en fazla israf ekmekte görülmektedir. Ona en yakın sırada; meyve-sebze, tahıl (buğday, pirinç vs.) ve süt gelmektedir. İsraf konusunda bireyler farklı yaklaşım sergileyebilmektedirler. Literatürde yer alan çalışmalarda israfın bireyler arasında farklı tanımlanabildiği ve mesela hayvanlara verilen gıdaların israf olarak değerlendirilmediği ifade edilmektedir. Bu nedenle bazı bireyler tüketemediği gıda maddelerini hayvanlara verdikleri zaman bireysel tüketimle eşdeğer tutmakta ve besinlerin israf edilmediğini kabul etmektedirler. Bu çalışmada israf; kişilerin kendileri veya yakınlarının tüketimi amacıyla satın aldıkları, ancak; farklı nedenlerden dolayı tüketilemeyen gıda kayıplarını tanımlamak için kullanıımıştır. 
Tablo 2. Katılımcıların Demografik Özellikleri

\begin{tabular}{|c|c|c|}
\hline Katılımcı sayısı: 324 & Sıklık & $\%$ \\
\hline \multicolumn{3}{|l|}{ Cinsiyet } \\
\hline Kadın & 173 & 47 \\
\hline Erkek & 151 & 53 \\
\hline \multicolumn{3}{|l|}{ Yaş } \\
\hline $18-30$ & 131 & 40 \\
\hline $31-45$ & 90 & 28 \\
\hline $46-58$ & 74 & 23 \\
\hline 59 ve üzeri & 29 & 9 \\
\hline \multicolumn{3}{|l|}{ Eğitim } \\
\hline Illköğretim & 27 & 8 \\
\hline Ortaöğretim & 40 & 13 \\
\hline Lise & 54 & 17 \\
\hline Üniversite & 131 & 40 \\
\hline Lisansüstü & 72 & 22 \\
\hline \multicolumn{3}{|l|}{ Medeni Durum } \\
\hline Bekar & 171 & 53 \\
\hline Evli & 153 & 47 \\
\hline \multicolumn{3}{|l|}{ Işs Durumu } \\
\hline Çalışıyor & 191 & 59 \\
\hline Çalışmıyor & 133 & 41 \\
\hline \multicolumn{3}{|l|}{ Aylık Hanehalkı Geliri } \\
\hline $2.000 \mathrm{tl}$ ve daha az & 60 & 19 \\
\hline $2.001-3.500 \mathrm{tl}$ & 65 & 20 \\
\hline $3.501-5.000 \mathrm{tl}$ & 70 & 21 \\
\hline $5.001-6.500 \mathrm{tl}$ & 47 & 15 \\
\hline $6.501 \mathrm{tl}$ ve yukarı & 82 & 25 \\
\hline
\end{tabular}

Tablo 3. Katılımcıların Gıda İsraf Deneyimleri

\begin{tabular}{lcc}
\hline Katılımcı Sayısı: 324 & Sıkık & $\%$ \\
\hline Hanede Gıda Israf Durumu & & \\
Sıklıkla & 35 & 11 \\
Arasıra & 98 & 30 \\
Nadiren & 143 & 44 \\
Hiç & 48 & 15 \\
Israf Edilen Gıda Grubu & & \\
$\quad$ Tahıl (Bulgur, Pirinç vs.) & 121 & \\
Meyve-Sebze & 179 & \\
Ekmek & 197 & \\
Et & 105 & \\
Süt & 118 & \\
Deniz Ürünleri & 108 & \\
Bakliyat (Nohut, Fasulye vb.) & 106 & \\
\hline
\end{tabular}

Türkiye'de özellikle ekmek kutsal değer olarak kabul edilmekte ve nimet olarak isimlendirilmektedir. Ancak buna karşın israfın en büyük boyutlara ulaştığı gıda gruplarından birini temsil etmektedir. Toprak Mahsulleri Ofisi (TMO) tarafından yapılan araştırmaya göre; Türkiye'de günlük üretilen ekmek 123 milyon adet, her gün israf edilen ekmek ise 6,14 milyon adettir. Ekmeğin yaklaşık \%5'i israf edilmektedir. Bu israfın 700 milyon \$'lık bir ekonomik kayıp yarattığı açıklanmıştır (TMO, 2014). Ekmek israfını sıklıkla yaşayan bireyler tarafından, bu durumun -genel kabul gören toplumsal değerlerle çelişmesi nedeniyle- bir suç olarak 
değerlendirilmesi mümkündür. Suç ve sorumluluğu başkalarına atfetmek, bireyleri rahatlatıcı bir unsur olarak değerlendirilebilir. TMO'nun yaptığı araştırmada (2014), ekmek israfı hakkındaki görüşleri sorulan katılımcıların yaklaşık \%98'i, ekmeği çöpe atmanın en kötü davranışlardan biri olduğunu belirtmiştir.

Çalışmanın takip eden kısmında değişkenlerin ve alt boyutların belirlenebilmesi amacıyla faktör analizi gerçekleştirilmiş ve faktör analizi sonucunda elde edilen boyutlar itibariyle katılımcıların bölümlendirilmesine ve tanımlanmasına yardımcı olacak kümeleme analizine başvurulmuştur.

\subsection{Faktör Analizi}

İtkisel satın alma davranışı ve algılanan kontrol değişkenlerinin ölçüldüğü sorulara keşfedici faktör analizi yapılmıştır. Faktör analizi yapılmasındaki temel amaç, kullanılan ölçeklerin yapısal geçerliliğinin ve sonraki analizler için kullanılacak boyutların belirlenebilmesidir.

Faktör analizine ilişkin bulgular ve güvenilirlik analizi (Cronbach alpha) değerleri aşağıdaki tabloda verilmiştir.

Tablo 4. Keşfedici Faktör Analizi - İtkisel Satın Alma/Algılanan Kontrol

\begin{tabular}{|c|c|c|c|c|}
\hline Faktör Boyutları ve ifadeler & $\begin{array}{l}\text { Faktör } \\
\text { Yükleri }\end{array}$ & KMO & $\begin{array}{c}\text { Açıklanan } \\
\text { Varyans } \\
(\%)\end{array}$ & $\begin{array}{c}\text { Güvenilirlik } \\
\text { (Cronbach } \\
\text { Alpha) }\end{array}$ \\
\hline itkisel Satınalma /Bilişsel itkisellik (Cognitive Impulsivity) & & 0,878 & 63,710 & 0,894 \\
\hline Faktör 1: Planlı Davranma Eğilimi & & & 32,631 & 0,857 \\
\hline Sadece gerçekten ihtiyacım olan şeyleri alırım & 0,835 & & & \\
\hline Bir şeyi satın almadan önce farklı markaları karşılaştırırım & 0,806 & & & \\
\hline Genelde sadece almayı amaçladığım şeyleri alırım & 0,794 & & & \\
\hline Alışverişlerimin çoğunu önceden planlarım & 0,787 & & & \\
\hline $\begin{array}{l}\text { Bir şey satın almadan önce ihtiyacım olup olmadığını etraflıca } \\
\text { düşünürüm }\end{array}$ & 0,746 & & & \\
\hline Bir şeyi satın almadan önce dikkatlice düşünürüm & 0,746 & & & \\
\hline Alışveriş listemde olmayan şeyleri satın almaktan kaçınırım & 0,614 & & & \\
\hline Bir şeyleri görür görmez satın almak benim tarzım değildir & 0,530 & & & \\
\hline Faktör 2: Itkisellik Eğilimi & & & 31,079 & 0,906 \\
\hline Genelde düşünmeden bir şeyler satın alırım & 0,863 & & & \\
\hline $\begin{array}{l}\text { Gerçekten ilginç bir şey gördüğümde sonuçlarını } \\
\text { düşünmeksizin onu satın alırım }\end{array}$ & 0,830 & & & \\
\hline Plansız satın almalar yapan biriyim & 0,826 & & & \\
\hline Sebepsiz olarak satın almak eğlencelidir & 0,799 & & & \\
\hline $\begin{array}{l}\text { Alışverişe çıktığımda almaya niyetli olmadığım bazı şeyleri } \\
\text { satın alırım }\end{array}$ & 0,766 & & & \\
\hline Bir şeyleri gördüğüm anda satın almaya alışığımdır & 0,761 & & & \\
\hline Kontrol Odağı & & 0,893 & 57,847 & 0,876 \\
\hline $\begin{array}{l}\text { Hayatımdaki önemli şeyleri değiştirmek için yapabileceğim } \\
\text { çok az şey var }\end{array}$ & 0,827 & & & \\
\hline Hayatın problemleriyle baş etmede çaresizim & 0,806 & & & \\
\hline Başıma gelen şeylerde çok az kontrole sahibim & 0,785 & & & \\
\hline Hayatın içinde itilip kakılıyorum & 0,785 & & & \\
\hline Kafama koyduğumu her zaman yapamayabilirim & 0,779 & & & \\
\hline Problemlerimin bir kısmını çözebilme imkânım gerçekten yok & 0,734 & & & \\
\hline Gelecekte başıma ne geleceği sadece bana bağlı değil & 0,581 & & & \\
\hline
\end{tabular}


Verplanken vd. (2001) tarafından geliştirilen itkisellik ölçeğinin bilişsel itkisellik boyutu ve Weun vd. (1997) tarafından geliştirilen itkisellik ölçeğinin ve kontrol odağı ölçeğinin (Perry ve Morris, 2005) faktör analizleri sonucunda itkisellik ölçeğinin planlı satın alma eğilimi ve itkisel satın alma eğilimi olarak isimlendirilen iki boyutu olduğu görülmektedir. Ölçeklerin ve alt boyutların güvenilirlik değerleri kabul edilebilir oranlardadır $(>0,60)$.

\subsection{Kümeleme Analizi}

Birçok çalışmada, katılımcıları tüketim alışkanlıklarına ve davranış eğilimlerine göre bölümlendirebilmek amacıyla kümeleme analizine başvurulmuştur (Knezevic vd., 2019). Kümeleme analizi, bireylerin veya uyarıcıların benzerliklerine göre gruplarda veya kümelerde toplanmasını sağlayan istatistiksel bir analizdir. Kümeleme analizi, önceden belirlenen seçme kriterine göre birbirine çok benzeyen birey ya da nesneleri aynı küme içinde sınıflandııır. Bu nedenle analiz sonucunda oluşan kümeler, kendi içinde homojendir (Kalaycı, 2005). Bu çalışmada, itkisel satın alma davranışına ilişkin ölçeği uygulanan faktör analizi sonucunda elde edilen 2 faktör boyutu itibariyle, katılımcıların farklı gruplar altında toplanıp toplanmadığını anlayabilmek için kümeleme analizi yapılmıştır.

Kümeleme analiz yöntemleri iki grupta kategorize edilmektedir. Bunlar; hiyerarşik ve hiyerarşik olmayan kümelemedir. Hiyerarşik kümelemenin en etkin ve yaygın kullanılan yöntemi hiyerarşik yığmacı yöntemdir. Yığmacı kümeleme yöntemlerinin yorumunun kolay oluşu en üstün tarafıyken, sabit olmayışı ve güvenilirliğinin az oluşu dezavantajlı yönüdür. Hiyerarşik olmayan kümelemede yer alan K-ortalamalar kümeleme basit ve hızlı sonuç veren bir kümeleme yöntemidir (Kalaycı, 2005). Mevcut çalışmada Kortalamalar hiyerarşik olmayan kümeleme yöntemi kullanılmıştır. K-ortalamalar kümelemesinde küme sayısı araştırmacı tarafından belirlenmektedir. K-Means kümeleme analizinde, küme sayısı katılımcıların kümelere dağılımları dikkate alınarak belirlenmiştir. Nihai olarak elde edilen analiz sonucu $\mathrm{F}$ skorları ve kümeler itibariyle dağılım Tablo 5'te yer almaktadır. Final küme merkezleri değişkenlerin kümeler itibariyle ortalamalarını göstermektedir. Söz konusu değişkenler faktör değerleri itibariyle analize alınması nedeniyle, ortalamaların daha iyi yorumlanabilmesi için değişkenlerin göreceli durumunu gösteren Şekil 1'e bakılabilir.

Tablo 5. Kümeleme Analizi Ortalama Skorları ve F Değerleri

\begin{tabular}{|c|c|c|c|c|}
\hline & Üye sayıları & $\begin{array}{c}\text { Faktör } 1 \\
\text { Planlı Satın } \\
\text { Alma Eğilimi }\end{array}$ & $\begin{array}{c}\text { Faktör } 2 \\
\text { Itkisel Satın } \\
\text { Alma Eğilimi }\end{array}$ & $\begin{array}{c}\text { Katılımcılar } \\
\text { içindeki pay } \\
(\%)\end{array}$ \\
\hline Küme $1^{*}$ & 95 & $-0,92854$ & $-0,82335$ & 29 \\
\hline Küme $2 * *$ & 62 & $-0,67897$ & 1,19153 & 19 \\
\hline Küme $3 * * *$ & 111 & 0,47786 & 0,54107 & 34 \\
\hline Küme $4 * * * *$ & 56 & 1,37973 & $-0,99491$ & 17 \\
\hline \multirow{2}{*}{\multicolumn{2}{|c|}{$\begin{array}{l}\text { ANOVA } \\
\text { sonuçları }\end{array}$}} & $F=321,016$ & $F=310,206$ & \\
\hline & & $P=0,000$ & $P=0,000$ & \\
\hline \multicolumn{5}{|c|}{$\begin{array}{l}\text { Küme Tanımları: } \\
\text { * Kendini ne planlı ne de itkisel satın alma eğiliminde görmeyenler } \\
\text { ** Planlıdan ziyade itkisel alışveriş yaptığını belirtenler } \\
\text { *** Zaman zaman planlı bazen itkisel alışveriş yaptığını ifade edenler } \\
\text { **** Genelde planlı alışveriş eğilimi sergileyenler }\end{array}$} \\
\hline
\end{tabular}

Şekil 1'de, çubuklar her bir küme için faktör boyutlarını temsil etmektedir. ilgili rengin sütun yüksekliği, o kümede hangi değişkenlerin en çok etkiye sahip olduğunu ve aralarındaki farkı göreceli olarak göstermektedir. Şekilde sunulan bilgiler kullanılarak, kümeler itibariyle tüketicilerin satın alma davranışlarına ilişkin özellikleri birbiriyle kıyaslanabilmektedir. Yukarıdaki tabloda paylaşılan küme tanımları şekildeki kümeler arasındaki farklııklar dikkate alınarak yapıımıştır. 


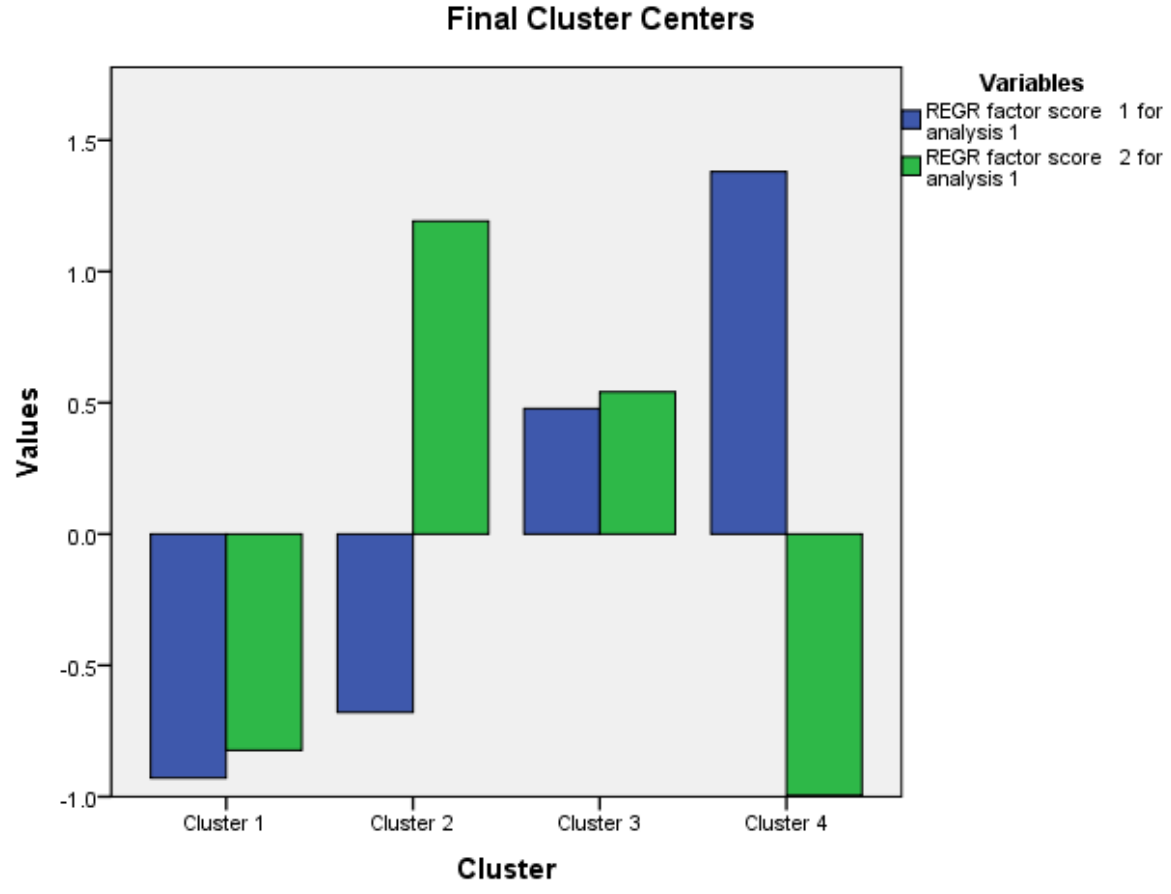

Tablo 5 ve Şekil 1'den anlaşılacağı üzere kümeleme analizi sonucunda katılımcılar 4 farklı gruba ayrılmıştır. Çubuk diyagramdan görüldüğü üzere; I. ve 3. Kümeler planlı ve itkisel satın alma eğilimi itibariyle diğer gruplardan -her iki davranış eğilimini de aynı yönlü sergilemesi itibariyle- ayrılmaktadır. 2. ve 4. Kümeler ise planlı ve itkisel satın alma eğilimleri açısından birbirinden tamamıyla ayrılan iki zıt grubu temsil etmektedir. Küme 2 daha çok itkisel satın alma eğilimi sergilerken, Küme 4 ise planlı satın alma eğilimi göstermektedir. En çok sayıda katılımcının yer aldığı küme ise 3. küme olup, bu katılımcılar da her iki davranışı da (planlı ve itkisel satın alma) zaman zaman sergileyen bir yapı hakimdir. Bir başka ifadeyle katılımcıların \%34'ünün alışverişlerinde nispeten itkisel davranma eğilimi göstermelerine karşın, aynı zamanda planlı davranma gayretlerinin de olduğu anlaşılmaktadır.

Katılımcıların itkisel ve planlı satın alma eğilimleri ile gıda israfı arasında bir ilişki olup olmadığını tespit edebilmek amacıyla, kategorik değerlere sahip bu iki değişkene parametrik olmayan ki-kare testi uygulanmıştır. Ki-kare testi sonucu Tablo 6 'da yer almaktadır. Test sonucunda iki değişken arasında istatistiki açıdan anlamlı bir ilişki bulunmuştur (Pearson chi-square: 55,327, df:9, p değeri: 0,000).

Tablo 6. Gıda İsraf Durumunun Kümeler İtibariyle Dağılımı

\begin{tabular}{lcccccc}
\hline & \multicolumn{5}{c}{ Küme Numaraları } & \\
\cline { 2 - 7 } & & 1 & 2 & 3 & 4 & Toplam \\
\hline \multirow{3}{*}{$\begin{array}{l}\text { Evinizde gıda israf edildiğini } \\
\text { düşünüyor musunuz }\end{array}$} & Sıklıkla & 3 & 5 & 9 & 18 & 35 \\
\cline { 2 - 7 } & Ara sıra & 25 & 12 & 38 & 23 & 98 \\
\cline { 2 - 7 } & Nadiren & 55 & 29 & 49 & 10 & 143 \\
\cline { 2 - 7 } & Hiç & 12 & 16 & 15 & 5 & 48 \\
\hline Toplam & & 95 & 62 & 111 & 56 & 324 \\
\hline
\end{tabular}


Tablo 6 incelendiğinde; israfı sıklıkla yaşadığını ifade eden kümenin, planlı satın alma eğiliminin daha yüksek olduğu 4. Küme olduğu görülmektedir. Planlı satın almanın israf konusunda daha önlemli davranmayı mümkün kılması tam tersi itkisel satın almada israfın daha sıklıkla yaşanması beklenirken, alışverişlerinde ihtiyaçlarını dikkate alan katılımcıların israfı yaşama yoğunluğunun daha yüksek olduğu dikkati çekmektedir. Çok farklı faktörler israfa neden olabilmektedir. Bu açıdan elde edilen bulgu değerlendirildiğinde, katılımcılar açısından satın alma eğilimleri, israfa neden olabilecek diğer faktörlerden daha önemli görülmemektedir. Daha önce de belirtildiği üzere Block vd. (2016); tüketicilerin yarattığı gıda israfının çoğunun, bilinçli bir şekilde farkında olunmayan veya tutumlarla açıklanmayan bir nedenle ortaya çıkabildiğini belirtmektedir. Yazarlara göre, gıda israfında bireyler kasti bir eylem içinde olmadığından, konuya psikolojik boyutlarla yaklaşmak gerekmektedir. Dolayısıyla planlı satın alma eğilimi sergileyenler arasında da satın alınan ürünün tüketilebileceği üzerine pozitif inancın olması planlama yapılsa da israfın yine de yaşanmasına neden olabilecektir.

Çalışmanın devamında 2. ve 4. Kümelerin atfetme ve kontrol algısı eğilimlerinin farklı olup olmadığı araştııılmıştır. 2. Küme itkisel satın alma eğilimi yüksek olanlar, 4. Küme ise planlı satın alma eğilimi yüksek olanlar olarak isimlendirilmiştir. İki grup arasında ilk olarak gıda israfına ilişkin sorumluluk ve suçluluk atfetme açısından bir farklılık olup olmadığını anlamak için bağımsız örneklemler $t$ testi yapılmıştır.

Tablo 7. Atfetme Eğilimleri İtibariyle Kümeler Arasındaki Farklılıklara İlişkin t-Testi

\begin{tabular}{lcc|c|c|c}
\hline & Küme Numarası & $\mathrm{N}$ & Ortalama & Std.Sap. & Std.Hata Ort. \\
\hline \multirow{2}{*}{\begin{tabular}{l} 
Sorumlu Kendim \\
\cline { 2 - 6 }
\end{tabular}} & 2 & 62 & 3,23 & 1,396 & 0,177 \\
\hline $\begin{array}{l}\text { Sorumlu Ailenin diğer } \\
\text { bireyleri }\end{array}$ & 2 & 56 & 1,46 & 0,660 & 0,088 \\
\hline $\begin{array}{l}\text { Sorumlu Satışa yönelik } \\
\text { işletme faaliyetleri }\end{array}$ & 4 & 62 & 3,16 & 1,345 & 0,171 \\
\hline \multirow{2}{*}{\begin{tabular}{l} 
Suçlu Kendim \\
\cline { 2 - 6 }
\end{tabular}} & 2 & 62 & 3,05 & 1,348 & 0,171 \\
\hline \multirow{2}{*}{\begin{tabular}{l} 
Suçlu Ailenin diğer bireyleri \\
\cline { 2 - 6 }
\end{tabular}} & 4 & 56 & 1,80 & 0,942 & 0,126 \\
\hline $\begin{array}{l}\text { Suçlu Satışa yönelik işletme } \\
\text { faaliyetleri }\end{array}$ & 2 & 62 & 3,13 & 1,443 & 0,183 \\
\hline
\end{tabular}

\begin{tabular}{l|c|c|c|c|c}
\hline & \multicolumn{2}{|c|}{ Levene Testi } & \multicolumn{3}{c}{ t-Testi Skorları } \\
\cline { 2 - 6 } & $\mathrm{F}$ & $\begin{array}{c}\text { Anlamlılık } \\
\text { (p değeri) }\end{array}$ & $\mathrm{t}$ & $\begin{array}{c}\text { Serb. } \\
\text { Der. }\end{array}$ & $\begin{array}{c}\text { Anlamlıık } \\
\text { (p değeri) }\end{array}$ \\
\hline \multirow{2}{*}{ Sorumlu Kendimi } & 49,812 & 0,000 & 8,613 & 116 & 0,000 \\
\hline \multirow{2}{*}{ Sorumlu Ailenin diğer bireyleri } & & & 8,898 & 88,868 & 0,000 \\
\hline \multirow{2}{*}{$\begin{array}{l}\text { Sorumlu Satışa yönelik işı. } \\
\text { faaliyetleri }\end{array}$} & 14,170 & 0,000 & 6,389 & 116 & 0,000 \\
\hline \multirow{2}{*}{ Suçlu Kendim } & 15,517 & 0,000 & 5,755 & 116 & 0,000 \\
\hline \multirow{2}{*}{ Suçlu Ailenin diğer bireyleri } & & & 5,857 & 109,357 & 0,000 \\
\hline \multirow{2}{*}{ Suçlu Satışa yönelik işl. faaliyetleri } & 26,597 & 0,000 & 6,402 & 116 & 0,000 \\
\cline { 2 - 6 } & & & 6,537 & 105,669 & 0,000 \\
\cline { 2 - 6 } & 26,784 & 0,000 & 6,346 & 116 & 0,000 \\
\hline
\end{tabular}


t testi sonucunda, 2. ve 4. Kümelerin sorumluluk ve suçu atfetme eğilimleri itibariyle farklılık gösterdiği görülmektedir (Tablo 7). Ortalamalara bakıldığında itkisel satın alma eğilimi sergileyenler; suç ve sorumluluk üstlenme itibariyle nispeten yüksek oranları temsil etmektedir. Sorumluğu kendine ve aile bireylerinde gören itkisel satın alma eğilimi yüksek olanlar, suçluluk atfında ise nispeten daha yüksek oranda pazarlama uygulamacılarını suçlamaktadırlar. Planlı satın alma davranışı sergileyenler ise; sorumluluk ve suçu nispeten kendilerine kıyasla daha yüksek oranda dışsal faktörlere yani aileye ve pazarlamacılara atfetmektedirler. Bu sonuç planlı davranış sergileyenler açısından çok şaşırtıcı görünmemektedir. Her iki grup kontrol odağı itibariyle değerlendirildiğinde ise; itkisel satın alma eğilimi sergileyenlerin birçok unsurun kontrolleri dışında olduğu yönündeki inançları daha yüksektir.

Tablo 8. Kontrol Odağı İtibariyle Kümeler Arasındaki Farklılıklara İlişkin t-Testi

\begin{tabular}{ccc|c|c|c}
\hline & \multicolumn{6}{c|}{$\begin{array}{c}\text { Küme } \\
\text { Numarası }\end{array}$} & $\mathrm{N}$ & Ortalama & Standart Sapma & Std. Hata. Ort. \\
\hline \multirow{2}{*}{ Kontrol Odağı } & 2 & 62 & 23,3710 & 7,27951 & 0,92450 \\
\cline { 2 - 6 } & 4 & 56 & 12,9643 & 6,18198 & 0,82610 \\
\hline
\end{tabular}

\begin{tabular}{cc|c|c|c|c}
\hline & \multicolumn{2}{c|}{ Levene Testi } & \multicolumn{3}{c}{ t-testi skorları } \\
\cline { 2 - 6 } & $\mathrm{F}$ & $\begin{array}{c}\text { Anlamlılı } \\
\mathrm{k}\end{array}$ & $\mathrm{t}$ & $\begin{array}{c}\text { Serb. } \\
\text { Der. }\end{array}$ & Anlamlılı \\
\hline Kontrol Odağı & 2,369 & 0,127 & 8,324 & 116 & 0,000 \\
\hline
\end{tabular}

Duygu durumları itibariyle iki küme arasındaki farka bakıldığında yine istatistiki olarak anlamlı bir farklılık görülmektedir (Tablo 9). İtkisel satın alma eğilimi sergileyenlerin en baskın hissettiği duygu; üzüntü iken, planlı satın alma davranışı sergileyenler ise daha fazla hayal kırıklığı yaşamaktadırlar. Rook ve Fisher (1995) ani dürtüler nedeniyle satın alma eğilimi sergileyen her beş müşteriden yaklaşık dördünün olumsuz duygular ve hisler yaşadığını belirtmektedir. Bununla birlikte bazı çalışmalarda da alışveriş yapanların istedikleri ürünü almama kararından dolayı üzüntü ve pişmanlık duyabildiklerini ileri sürülmektedir (Hoch ve Loewenstein, 1991; Parsad vd., 2019). İtkisel davrananların planlı satın alma eğilimi sergileyenlere kıyasla daha az hayal kırıklığı yaşamalarının bir nedeni; gıda israfını daha az deneyimlemeleri olabilir.

Tablo 9. Duygu Durumları İtibariyle Kümeler Arasındaki Farklılıklara Ilişkin t-Testi

\begin{tabular}{lcc|c|c|c}
\hline \multirow{2}{*}{ Küme Numarası } & $\mathrm{N}$ & $\begin{array}{c}\text { Ortalam } \\
\mathrm{a}\end{array}$ & Std. Sapma & \multirow{2}{*}{ Std. Hata Ort. } \\
\hline \multirow{2}{*}{ Kızgınlık } & 2 & 62 & 3,27 & 1,439 & 0,183 \\
\cline { 2 - 6 } & 4 & 56 & 1,66 & 0,900 & 0,120 \\
\cline { 2 - 6 } Hayal kırıklığı & 2 & 62 & 3,23 & 1,396 & 0,177 \\
\hline \multirow{2}{*}{ Şaşırma } & 4 & 56 & 1,95 & 1,069 & 0,143 \\
\hline \multirow{2}{*}{ Tiksinti } & 2 & 62 & 3,47 & 1,238 & 0,157 \\
\hline \multirow{2}{*}{ Üzüntü } & 4 & 56 & 1,75 & 0,879 & 0,117 \\
\hline \multirow{2}{*}{ Utanç } & 2 & 62 & 3,55 & 1,263 & 0,160 \\
\hline \multirow{2}{*}{ Çok takılmama } & 4 & 56 & 1,82 & 0,897 & 0,120 \\
\cline { 2 - 6 } & 2 & 62 & 3,56 & 1,301 & 0,165 \\
\hline
\end{tabular}


Kümelerin cinsiyet ve gelir itibariyle dağılımlarına ilişkin bilgiler Tablo 10'da görülmektedir. İtkisellik eğilimi birçok araştırmadan (Harwani ve Kanade, 2017; Sangalang vd., 2017; Akçay ve Özdemir, 2019) farklı bir şekilde, erkeklerde daha yüksek çıkmıştır. Erkeklerin kadınlara göre daha itkisel davrandığına işaret eden araştırma bulguları da paylaşıımıştır (Awan ve Abbas, 2015; Öz ve Mucuk, 2015). Burada dikkate alınması gereken husus; alışverişe konu olan ürünün cinsidir. Giyim, kozmetik vs. ürün gruplarında kadınların itkisellik eğilimleri daha yüksek bulunurken, gıda satın alımlarında erkeklerin ön plana geçmesi, nispeten anlaşılabilir bir bulgudur.

Tablo 10. Cinsiyetin ve Aylık Aile Gelirinin Kümeler İtibariyle Dağılımı

\begin{tabular}{lcc|c|c}
\hline & \multicolumn{2}{c|}{ Cinsiyet } & \multirow{2}{*}{ Toplam } \\
\cline { 2 - 4 } & Kadın & Erkek & \\
\hline & 2. Küme & 28 & 34 & 62 \\
\cline { 2 - 4 } & 4. Küme & 32 & 24 & 56 \\
\hline Toplam & 173 & 151 & 324 \\
\hline
\end{tabular}

\begin{tabular}{cccccccc}
\hline & \multicolumn{5}{c}{ Aylık aile geliri } & \\
\cline { 2 - 7 } & \multirow{2}{*}{2000 TL ve altı } & $\begin{array}{r}2001- \\
3500\end{array}$ & $3501-5000$ & $\begin{array}{c}5001- \\
6500\end{array}$ & 6501 TL ve üstü & Toplam \\
\hline 2. Küme & 9 & 6 & 12 & 16 & 19 & 62 \\
\cline { 2 - 7 } 4. Küme & 23 & 15 & 8 & 5 & 5 & 56 \\
\hline Toplam & 60 & 65 & 70 & 47 & 82 & 324 \\
\hline
\end{tabular}

Gelir dağılımı itibariyle araştırma sonuçları, literatürde yer alan çalışmalarla uyumludur (Ciunova ve Shuleska, 2012; Harwani ve Kanade, 2017). Planlı satın alma eğilimi düşük gelir düzeyine sahip bireylerde diğerlerine kıyasla daha yüksektir.

\section{Sonuç}

İsraf, çağımızın sorunu olarak tanımlanacak bir boyut kazanmıştır. Özellikle gıda israfı bir taraftan insanların açlıkla mücadele ettiği bir dünyada ironik ve daha da sıkıntılı bir durumu ortaya çıkarmaktadır. Giderek daha da büyüyen bu probleme ilişkin çözüm önerilerinin getirilebilmesi büyük önem taşımaktadır.

İsraf tüketim noktasında bir başka ifadeyle hanelerde ortaya çıkmaktadır. Hanelerdeki israfın azaltılması konusunda farkı çözüm yolları uygulanmakta ve yenileri araştırılmaktadır. Bu noktada bireylerin israfa yönelik genel değerlendirmeleri ve alışveriş eğilimlerinin israf yaratma durumu konusunda bilgi ihtiyacının olduğu görülmektedir. Konu üzerine yapılan araştırmalar genelde israfın genel nedenleri ve sonuçlarıyla ilgili olarak gerçekleştirilmiştir. Bu çalışmada tüketicilerin satın alma eğilimleri (itkisel ve planlı) ve israf ilişskisi değerlendirilmiştir.

Toplanan verilere uygulanan analizler sonucunda itkisellik ile israf arasında bir ilişki bulunmasına karşın bu ilişkinin israfı artıracak boyutta olmadığı görülmüştür. Planlı alışveriş yaptığını söyleyenlerin de išrafı sıklıkla yaşıyor olmaları, farklı faktörlerin israfı oluşturduğunu düşündürmektedir.

Konu üzerine yapılan bir araştırmada gıda israfında etkili çok değişkenin varlığından bahsedilirken sosyo-demografik özelliklerin burada çok belirleyici olmadığı vurgulanmıştır. Sadece hanenin genel özelliklerini göstermesi açısından bir rol oynayabileceğinden bahsedilmiştir. Mesela yaş faktörü etkilidir evet ancak yaştan ziyade mesela belli bir yaş grubunun savaş sonrası döneme denk gelmesi kıtlık yaşaması vs. gibi faktörlerin gıda israfına bakışını etkilediği belirtilmektedir veya gıda güvenliği konusunda hassasiyet gösterilmesinin çocuklu ailelerde daha fazla olabileceği, bekarların ise plansızlık veya pratiklik/kolaylık gibi unsurlara tüketimlerinde daha fazla dikkat edebileceği ifade edilmiştir. Sosyodemografik özelliklerden daha fazla psikodemografik özelliklerin önemine işaret edilmiştir (Aschemann-Witzel vd., 2015) 
İtkisel ve planlı alışveriş eğilimi sergileyenlerin sorumluluk/suçu üstlenip üstlenmediğine ilişkin sonuçlar, her iki grupta da israfın sorumluluğunu hem kendi üzerine aldığını, hem de pazarlama uygulamacılarına yansıttıklarını göstermektedir. Ancak itkisel satın alma eğilimi sergileyenler her ne kadar sorumluluğu üstlenseler de israfta pazarlama uygulamacılarını suçlamaktadırlar. İsraftan dolayı pazarlama uygulamacılarının suçlanmasının temel nedeni kalıp yargılar olabilir. Bir kişi, grup veya markayla ilgili bilgiler bazen bireylerin genel algılarını şekillendirmektedir: "Pazarlamacılar insanların daha fazla satın almalarını sağlarlar". Ayrıca tüketicilerin atfetme sürecine pazarlama/reklam mesajı, ürün, pazarlamacı, alışveriş çevresi, tüketicinin kendisi gibi birçok unsur dahil olmaktadır (Ay ve Kahraman, 2014).

İsrafın mağaza ve perakendecilerde gerçekleşen kısmı kayıp olarak isimlendirilmektedir. Perakendecilerin satamadıkları gıdaları imha etmeleri ve raf ömrü doldurmuş ürünleri bir kayıp olarak değerlendirmeleri mümkündür. Perakendeciler bazı durumlarda bu konuda tüketicilerin yetersiz satın alma miktarlarını gerekçe olarak göstermekte (Aschemann-Witzel vd., 2015) ve bozulabilirliği yüksek ürünlerin satışlarını gerçekleştirmek için farklı fiyatlandırma ve satış artırıcı önlemler uygulama durumunda kalmaktadırlar. Bu çerçeveden bakıldığında perakendecilerin ürün satışlarını artırmak için gerçekleştirdiği faaliyetlerin temel nedeninin de kazanç ve karlılı̆ı artırmanın yanı sıra mağaza içi gıda israfını önlemek olduğunu söylemek yanlış olmayacaktır. Nitekim Aschemann-Witzel vd. (2015) gerçekleştirdikleri çalışmada gıda perakendecilerine, müşterilerine sundukları fiyat ve ambalaj alternatiflerini iyi test etmeleri ve sağıkılı bir fiyatlandırma ile ürün satışlarının artırılmasının ve mağaza içi gıda israfının minimuma indirilmesinin mümkün olabileceği ifade edilmektedir. Ancak mağaza içi kayıpları azaltmak için uygulanan satış geliştirme çalışmaları bu sefer tüketicilerin pazarlamacılara ilişkin tutumlarını negatif etkilemektedir. Bu noktada pazarlama uygulamacıları açısından önerilebilecek yaklaşım; işbirliği oluşturacak programların geliştirilmesidir. İsrafın azaltılması konusunda tüketici görüşlerine başvurulması ve bunların işlevselleştirilmesi tüketiciler açısından marka/işletme hakkında pozitif yorumlamaların yapılmasını mümkün kılabilecek ve israfın azaltılması yönünde etkide bulunabilecektir.

\section{Beyan ve Açıklamalar (Disclosure Statements)}

1. Bu çalışmanın yazarları, araştırma ve yayın etiği ilkelerine uyduklarını kabul etmektedirler (The authors of this article confirm that their work complies with the principles of research and publication ethics).

2. Yazarlar tarafından herhangi bir çıkar çatışması beyan edilmemiştir (No potential conflict of interest was reported by the authors).

3. Bu çalışma, intihal tarama programı kullanılarak intihal taramasından geçirilmiştir (This article was screened for potential plagiarism using a plagiarism screening program).

\section{Kaynaklar}

Akçay, G., \& Özdemir, E. (2019). Demografik özellikler açısından tüketicilerin plansız satın alma davranış farklııılarını incelemeye yönelik bir araştırma. OPUS Uluslararası Toplum Araştırmaları Dergisi, 14(20), 817-846.

Aksoy, M., \& Solunoğlu A. (2015). Gıda israfı ve freegan food akımı. I. Eurasia International Tourism Congress: Current Issues, Trends and Indicators (EITOC-2015) 28-30 Mayıs, Konya, 165-172.

Altunışık R., Torlak, Ö., \& Özdemir, Ş. (2017). Pazarlama ilkeleri ve yönetimi. Beta Yayınları.

Altunışık, R., Coşkun, R., Bayraktaroğlu, S., \& Yıldıım, E. (2012). Sosyal bilimlerde araştırma yöntemleri (SPSS uygulamalı) (7. Baskı). Sakarya Yayıncılık.

Aschemann-Witzel, J., De Hooge, I., Amani, P., Bech-Larsen, T., \& Oostindjer, M. (2015). Consumer-related food waste: Causes and potential for action. Sustainability, 7(6), 6457-6477.

Awan, A. G., \& Abbas, N. (2015). Impact of demographic factors on impulse buying behavior of consumers in MultanPakistan. European Journal of Business and Management, 7(22), 96-105.

Ay, C., \& Kahraman A. (2014). Atfetme (nedensellik yükleme) teorisi. Pazarlama Teorileri içinde, ed. Mehmet İsmail Yağcı ve Serap Çabuk, MediaCat Yayınları, 113-130. 
Aydemir, S. D. (2015). Duygusal zeka, kontrol odağı, genel olarak riskten kaçınma ve finansal okuryazarlığın riskli yatırım niyeti üzerindeki etkisi. Gebze Teknik Üniversitesi SBE, Yayınlanmamış Doktora Tezi, Gebze.

Aytekin P., \& Ay, C. (2015). Hedonik tüketim ve anlık satın alma ilişkisi. Niğde Üniversitesi iiBF Dergisi, 8(1), $141-156$.

Bahar, R., (2019). Otomotiv sektöründe müşterilerin atfetme eğilimlerinin marka güveni ve müşteri memnuniyeti perspektifinden incelenmesi. Balıkesir Üniversitesi Sosyal Bilimler Enstitüsü, Yayımlanmamış Doktora Tezi, Balıkesir.

Bell, S. T., Kuriloff, P. J., \& Lottes, I. (1994). Understanding attributions of blame in stranger rape and date rape situations: An examination of gender, race, identification, and students' social perceptions of rape victims. 1. Journal of Applied Social Psychology, 24(19), 1719-1734

Block, L. G., Keller, P. A., Vallen, B., Williamson, S., Birau, M. M., Grinstein, A., ... \& Moscato, E. M. (2016). The squander sequence: Understanding food waste at each stage of the consumer decision-making process. Journal of Public Policy \& Marketing, 35(2), 292-304.

Boz, H., \& Koc, E. (2018). İtkisel (dürtüsel) satın alma davranışının nedenleri ve sonuçları: Turizm ve konaklama sektöründe bir çalışma. International Journal of Social Inquiry, 11(2), 17-45

Ciunova-Shuleska, A. (2012). The impact of situational, demographic, and socioeconomic factors on impulse buying in the republic of Macedonia. Journal of East-West Business, 18(3), 208-230.

Demirbaş, N. (2019). Gıda arz zincirindeki kayıp ve israfın azaltılmasında ambalajın önemi ve gelişmeler. 9-10 Mart XI. IBANESS Kongreler Serisi, 627-632.

Dölekoğlu, C. Ö. (2017). Gıda kayıpları, israf ve toplumsal çabalar. Tarım Ekonomisi Dergisi, 23(2), 179-186.

Dursun, T., \& Yener, D. (2014). İçgüdüsel satınalma ölçeklerinin Türk tüketiciler için uyarlanmasına yönelik hazır giyim sektöründe bir uygulama. Ejovoc (Electronic Journal of Vocational Colleges), 4(1), 22-31.

Ertürk, A., Arslantaş, N., Sarıca, D., \& Demircan, V. (2015). Isparta ili kentsel alanda ailelerin ekmek tüketimi ve israfı. Akademik Gıda, 13(4), 291-298.

FAO, (2009). Global agriculture towards 2050. http://www.fao.org/fileadmin/templates.. HLEF2050_Global_Agriculture.pdf (Erişim Tarihi: 10.03.2020).

FAO, (2011). http://www.fao.org/turkey/en/ (Erişim Tarihi: 10.12.2019).

FAO, (2013). Definitional framework of food loss, Food and Agriculture Organization of The United Nations (FAO). Save Food: Global Initiative on food loss and waste reduction working paper. http://www.fao.org (Erişim Tarihi: 13.01.2020).

Graham-Rowe, E., Jessop, D. C., \& Sparks, P. (2015). Predicting household food waste reduction using an extended theory of planned behaviour. Resources, Conservation and Recycling, 101, 194-202.

Gustavsson, J., Cederberg, C., Sonesson, U., Otterdijk, R. V., \& Meybeck, A. (2011). Global food losses and food waste extent, causes and prevention. Food and Agriculture Organization of the United Nations (FAO), ISBN 978-92-5107205-9.

Harwani, S., \& Kanade, S. R. (2017). Impact of demographic differences and other factors on impulse buying. International Journal of Management (IJM), 8(2), 58-67.

Hoch, S. J., \& Loewenstein, G. F. (1991). Time-inconsistent preferences and consumer self-control. Journal of Consumer Research, 17(4), 492-507.

Kacen, J. J., \& Lee, J. A. (2002). The influence of culture on consumer impulsive buying behavior. Journal of Consumer Psychology, 12(2), 163-176.

Kalaycı, Ş. (2005). SPSS uygulamalı çok değişkenli istatistik teknikleri (1. Baskı). Asil Yayın Dağıtım.

Knezevic, B., Kurnoga N., \& Anic, I. D. (2019). Typology of university students regarding attitudes towards food waste. British Food Journal, 121(1), 2578-2591.

Koç, E., (2019). Tüketici davranışı ve pazarlama stratejileri (8. Baskı). Seçkin Yayıncılık.

Koç, E., \& Boz, H. (2014). Triangulation in tourism research: A bibliometric study of top three tourism journals. Tourism Management Perspectives, 12, 9-14.

Madhavaram, S. R., \& Laverie, D. A. (2004). Exploring impulse purchasing on the internet. Advances in Consumer Research, 31(1), 59-66.

Maymon, R., Hall, N. C., Goetz, T., Chiarella, A., \& Rahimi, S. (2018). Technology, attributions, and emotions in postsecondary education: An application of Weiner's attribution theory to academic computing problems. PloS one, 13(3),1-36. 
Murugarantham, G., \& Shankar, B. R. (2013). A review of Impulse buying behavior. International Journal of Marketing Studies, 5(3), 149-160.

Newsone, T. M., \& Eeden, L. M. V. (2017). The effects of food waste on wildlife and humans. Sustainability, 9, 1269.

Oladipo, J. O. (2019). Effects of personal selling on consumer impulse buying behaviors: Evidence from selected quoted foods and beverages firms in Nigeria. Global Journal of Management and Business Research: E-Marketing, 19(4), 17-24.

Öz, M., \& Mucuk, S. (2015). Tüketici satın alma davranışı kapsamında hedonik (hazcı) tüketimin plansız alışveriş üzerine etkilerinin incelenmesi. Pazarlama Teorisi ve Uygulamaları Dergisi, 1(2), 37-60.

Parfitt, J., Barthel, M., \& Macnaughton, S. (2010). Food waste within food supply chains: Quantification and potential for change to 2050. Philosophical Transactions of the Royal Society B, 3065-3081.

Parsad, C., Prashar, S., Vijay, T. S., \& Sahay, V. (2019). Role of in-store atmospherics and ımpulse buying tendency on post-purchase regret. Journal of Business and Management, 25(1), 1-24.

Piron, F. (1991). Defining Impulse Purchasing. ACR North American Advances: Vol. 18, ed. Rebecca H. Holman ve Michael R. Solomon, Provo, UT: Association for Consumer Research, 509-514.

Porpino, G., Parente, J., \& Wansink, B. (2015). Food waste paradox: antecedents of food disposal in low income households. International Journal of Consumer Studies, 39(6), 619-629.

Quested, T. E., Marsh, E., Stunell, D., \& Parry, A. D. (2013). Spaghetti soup: The complex world of food waste behaviours. Resources, Conservation and Recycling, 79, 43-51.

Perry, V. G., \& Morris, M. D. (2005). Who is in control? The role of self perception, knowledge, and income in explaining consumer financial behavior. Journal of Consumer Affairs, 39(2), 299-313.

Rook, D. W., \& Fisher, R. J. (1995). Normative influences on impulsive buying behavior. Journal of Consumer Research, 22(3), 305-313.

Rook, D. W., \& Gardner, M. P. (1993). In the mood: Impulse buying's affective antecedents. Research in Consumer Behavior, 6(7), 1-28.

Saklakoğlu, T. (2018). The effects of personality traits on impulse buying behavior. Bahçeşehir Üniversitesi SBE, Yayınlanmamış Yüksek Lisans Tezi, İstanbul.

Salihoglu, G., Salihoglu, N. K., Ucaroglu, S., \& Banar, M. (2018). Food loss and waste management in Turkey. Bioresource Technology, 248, 88-99

Sangalang, R. A., Siochi, J., \& Plaza, M. (2017). Factors influencing consumers' impulse buying behavior in the fifth district of Cavite. In DLSU Research Congress, 1-6.

Stefan, V., van Herpen, E., Tudoran, A. A., \& Lähteenmäki, L. (2013). Avoiding food waste by Romanian consumers: The importance of planning and shopping routines. Food Quality and Preference, 28(1), 375-381.

Tarım ve Orman Bakanlığı, (2015). G20 tarım üst düzey görevliler 3. toplantısı gerçekleştirildi. https://www.tarimorman.gov.tr (Erişim Tarihi: 15.01.2020).

Taşkın, Ç., \& Özdemir Ö. (2017). Online itkisel satın alma davranışının öncülleri üzerine bir araştırma. Mehmet Akif Ersoy Üniversitesi Sosyal Bilimler Enstitüsü Dergisi, 9(18), 251-270.

Toprak Mahsulleri Ofisi (TMO), (2014). Ekmek israfı ve tüketici alışkanlıkları. http://www.tmo.gov.tr/Upload/Document/ekmek/tmobrosuryeni2.pdf (Erişim Tarihi: 09.03.2020).

Torlak, Ö., \& Tiltay, M. A. (2010). Anlık satın alma ölçeklerinin Türk tüketicisi için uyarlanmasına yönelik bir deneme. Ulusal Pazarlama Kongresi, İzmir, 406-422.

Türkiye İstatistik Kurumu (TUIK), (2020). Nüfus ve demografi istatistikleri. http://www.tuik.gov.tr/UstMenu.do?metod=temelist (Erişim Tarihi: 20.05.2020).

Verplanken, B. Astrid Herabadi (2001). Individual differences in impulse buying tendency: feeling and no thinking", European Journal of Personality, 15, 71-83.

Yeniçeri, T., Yaraş, E., \& Akın E. (2012). Tüketicilerin riskten kaçınma düzeylerine göre sanal alışveriş risk algısı ve sanal plansız tüketim eğilimlerinin belirlenmesi. Uluslararası İktisadi ve idari Incelemeler Dergisi, 5(9), 145-164.

Weun, S., Jones, M. A., \& Beatty, S. E. (1997). A parsimonious scale to measure impulse buying tendency. AMA Educators's proceedings: enhancing knowledge development in marketing, 306-307.

Williamson, S., Block L.G., \& Keller P. A. (2016). Of waste and waists: the effect of plate material on food consumption and waste. Journal of the Association of Consumer Research, 1 (1), 147-60. 
This Page Intentionally Left Blank 